Karel A.C. De Schamphelaere ORCID iD: 0000-0002-5063-922X

20-00102

Environmental Toxicology

C. Nys et al.

A chronic juvenile rainbow trout gBAM

\title{
A generalized bioavailability model (gBAM) for predicting chronic copper toxicity to freshwater fish
}

\author{
Charlotte Nys, ${ }^{\mathrm{a}, *}$ Karel Vlaeminck, ${ }^{\mathrm{a}, \mathrm{b}}$ Patrick Van Sprang, ${ }^{\mathrm{a}}$ and Karel AC De \\ Schamphelaere ${ }^{\mathrm{b}, \mathrm{c}}$ \\ ${ }^{\mathrm{a} A R C H E}$ Consulting, Ghent (Wondelgem), Belgium \\ ${ }^{\mathrm{b}}$ GhEnToxLab, Department of Animal Science and Aquatic Ecology, Ghent University, \\ Ghent, Belgium \\ ${ }^{\mathrm{c} S y r a l u t i o n, ~ D e i n z e, ~ B e l g i u m ~}$
}

(Submitted 24 February 2020; Returned for Revision 3 April 2020; Accepted 16 June 2020)

This article has been accepted for publication and undergone full peer review but has not been through the copyediting, typesetting, pagination and proofreading process, which may lead to differences between this version and the Version of Record. Please cite this article as doi: 10.1002/etc.4806.

This article is protected by copyright. All rights reserved. 
Abstract: The generalized bioavailability model (gBAM) has been proposed as an alternative to the biotic ligand model (BLM) for modeling bioavailability and chronic toxicity of copper. The gBAM combines a log-linear effect of $\mathrm{pH}$ on free $\mathrm{Cu}^{2+}$ ion toxicity with BLM-type parameters for describing the protective effects of major cations $\left(\mathrm{Ca}^{2+}, \mathrm{Mg}^{2+}\right.$, and $\left.\mathrm{Na}^{+}\right)$. In the present study, a WHAM VII-based gBAM for fish has been parametrized based on an existing chronic (30d-mortality) dataset of juvenile rainbow trout (Oncorhynchus mykiss). The model, with the following parameters $\mathrm{S}_{\mathrm{pH}}=0.4449, \log$ $\mathrm{K}_{\mathrm{CaBL}}=4.0, \log \mathrm{K}_{\mathrm{MgBL}}=3.4$ and $\log \mathrm{K}_{\mathrm{NaBL}}=3.0$, was shown to accurately predict the effects of $\mathrm{pH}, \mathrm{DOC}, \mathrm{Ca}$, and $\mathrm{Mg}$ on chronic $\mathrm{Cu}$ toxicity to juvenile rainbow trout at the effect levels relevant for environmental risk assessment (i.e. median prediction error of 1.3-fold for $10 \%$ and $20 \%$ lethal concentrations). The gBAM predicted the effect of $\mathrm{pH}$ more accurately than a previously published Cu BLM for juvenile rainbow trout, especially at $\mathrm{pH}>8$. We also evaluated the cross-species and cross-life-stage applicability of the newly developed juvenile rainbow trout gBAM using existing chronic Cu toxicity data with early life-stages of fathead minnow (Pimephales promelas) and rainbow trout. We did this because using a single bioavailability model for all fish species and life-stages is practical from a regulatory point of view. Although the early life-stage datasets exhibit considerable uncertainties, $91 \%$ of the considered toxicity values at the effect levels most relevant in European environmental regulations (10\% effect on survival or growth) were predicted within 2-fold error. Overall, the chronic Cu gBAM developed here is a valuable alternative for the existing chronic Cu BLM for rainbow trout and performs sufficiently well to be used in risk assessment according to currently accepted standards of bioavailability model performance (from the current European regulatory point of view).

This article is protected by copyright. All rights reserved. 
Yet, our analysis also suggests that bioavailability relations differ between different fish life-stages and between endpoints (e.g. mortality vs. growth), which is currently not accounted for in environmental risk assessments.

Keywords: bioavailability, biotic ligand model, ecological risk assessment, aquatic toxicology

This article includes online-only Supplemental Data.

*Address correspondence to charlotte.nys@arche-consulting.be

Published online XXXX 2020 in Wiley Online Library (www.wileyonlinelibrary.com).

DOI: 10.1002/etc.Xxxx

\section{INTRODUCTION}

Bioavailability models, such as the biotic ligand model (BLM), are increasingly being used to account for the influence of water chemistry variables (e.g., pH, water hardness and dissolved organic carbon, [DOC]) on ecotoxicity and ecological risks of copper in surface waters. For instance, chronic copper BLMs have been implemented in the European Union (EU) to derive predicted no effect concentrations (PNEC) in the risk assessment performed under the former Existing Substances Regulation-directive (EC 1993), now replaced by the Registration, Evaluation, Authorization and Restriction of Chemicals (REACH)-directive (EC 2006, ECI 2008). In addition, chronic Cu BLMs are also used to derive site-specific environmental quality standards (EQS) (EC 2013; Rüdel et al. 2015). The current procedure for deriving bioavailability-based PNECs and EQS, as

This article is protected by copyright. All rights reserved. 
defined in the Cu Voluntary Risk Assessment Report (Cu VRAR; ECI 2008), is based on normalization of toxicity data with chronic $\mathrm{Cu}$ bioavailability models for three trophic levels: a Daphnia magna Biotic Ligand Model (BLM) (De Schamphelaere \& Janssen 2004), an algae generalized Bioavailability Model (gBAM) (De Schamphelaere \& Janssen 2006) and a fish BLM (De Schamphelaere \& Janssen 2008).

The chronic $\mathrm{Cu}$ fish BLM currently used in EU risk assessment (RA) is based on a more than 10-year-old analysis (De Schamphelaere and Janssen, 2008) of two chronic toxicity datasets (Erickson et al. 1996; Waiwood and Beamish, 1978a,b). Due to the limited availability of fish data to develop a fish-specific chronic BLM at that time, De Schamphelaere and Janssen (2008) evaluated which of three 'animal' Cu BLMs that already existed (i.e. developed based on acute fish, acute Daphnia, or chronic Daphnia toxicity data) performed best in explaining bioavailability effects on chronic copper toxicity to fish. Growth rate was the only endpoint considered, because it was the most sensitive endpoint in both fish toxicity datasets. The acute Daphnia BLM outperformed the two other BLMs, and was therefore selected to serve as the chronic copper BLM for fish in EU risk assessment applications (De Schamphelaere and Janssen 2008; ECI 2008; hereafter named chronic ' $C u$ VRAR Fish BLM'). This BLM adequately explained the variability of $\mathrm{Cu}$ toxicity among different test media that was due to the effects of $\mathrm{pH}$, hardness $\left(\mathrm{Ca}^{2+}\right.$ and $\left.\mathrm{Mg}^{2+}\right)$ and $\mathrm{Na}^{+}$on growth of early-life stages (ELS) of fathead minnow (Pimephales promelas) and juvenile rainbow trout (Oncorhynchus mykiss) (De Schamphelaere and Janssen, 2008).

Recently, new chronic toxicity datasets for juvenile rainbow trout (RT) (Cremazy et al. 2017) and early-life stages of fathead minnow and rainbow trout (OSU, 2016a,b, 2017) This article is protected by copyright. All rights reserved. 
have become available and a de novo chronic juvenile rainbow trout BLM was developed by Cremazy et al. (2017, hereafter referred to as 'chronic juvenile RT BLM'). The latter model has been shown to capture the protective effects of $\mathrm{Mg}^{2+}, \mathrm{Ca}^{2+}$ and DOC on chronic Cu toxicity (Cremazy et al. 2017). However, the chronic juvenile RT BLM was not able to entirely capture the effect of $\mathrm{pH}$ on chronic $\mathrm{Cu}$ toxicity to juvenile rainbow trout, especially at high $\mathrm{pH}(\mathrm{pH} \geqq 8)$. This suggests that the parametrization of the effect of $\mathrm{pH}$ in the chronic juvenile RT BLM is not entirely sufficient. Both existing fish BLMs formulate the effect of $\mathrm{pH}$ on free $\mathrm{Cu}^{2+}$ ion toxicity as a linear single-site competition effect of $\mathrm{H}^{+}$at the $\mathrm{Cu}^{2+}$ uptake site (i.e. the biotic ligands). An alternative formulation of the $\mathrm{pH}$ effect in the chronic $\mathrm{Cu}$ Daphnia bioavailability model has recently been proposed through the use of generalized bioavailability models (gBAMs) (Van Regenmortel et al. 2015).

gBAMs are an alternative to the existing BLMs to predict chronic effect concentrations for copper (and other metals) to freshwater organisms (Mebane et al. 2020), such as fish (e.g., Ni Deleebeeck et al. 2007), Daphnia magna (e.g., for Cu and Zn: Van Regenmortel et al. 2015; 2017) and algae (e.g., for Cu: De Schamphelaere \& Janssen 2006). The chronic $\mathrm{Cu}$ Daphnia gBAM combines a log-linear $\mathrm{pH}$-effect on free $\mathrm{Cu}^{2+}$ ion toxicity with conventional linear protective effects of major cations. A similar parametrization of the effect of $\mathrm{pH}$ on $\mathrm{Cu}^{2+}$ toxicity is also used in the algae gBAM currently implemented in the risk assessment approach of the Cu Voluntary Risk Assessment Report (VRAR; ECI 2008). Due to its log-linear model structure, gBAMs may account for other factors that determine the effect of $\mathrm{pH}$ on $\mathrm{Me}^{2+}$ toxicity besides the competitive effect of $\mathrm{H}^{+}$at the biotic ligand site (discussed in more detail in the Discussion section). For D. magna,

This article is protected by copyright. All rights reserved. 
the gBAM provided a better prediction of the effect of $\mathrm{pH}$ on $\mathrm{Cu}^{2+}$ ion toxicity than the chronic Daphnia Cu-BLM and required two parameters less to be calibrated (Van Regenmortel et al. 2015).

Moreover, geochemical equilibrium speciation modelling of metals, including copper, in the presence of dissolved organic carbon (DOC) has also advanced over the past decade. The Windermere Humic Aqueous Model (WHAM) V is still the speciation model underlying all $\mathrm{Cu}$ BLMs used in the EU-RA. Currently, the use of WHAM VII is gaining increased interest in the scientific community (Tipping et al. 2011, Lofts \& Tipping 2011). The WHAM VII software is much more flexible and more user-friendly to work with than the WHAM V software. Van Regenmortel (2017) recently showed that switching metal bioavailability models for copper from WHAM V to WHAM VII maintains similar predictive capacities of metal toxicity to D. magna and algae. Given the upcoming challenge of integrating metal mixture toxicity in environmental legislation, an update and uniformization of the underlying geochemical speciation model for metal bioavailability modelling, which currently differ between different metals, seems to be indispensable (Nys et al. 2018).

Based on the above reasoning, the aim of the present study was to evaluate if a WHAM VII-based gBAM could be a valuable alternative for the currently used Cu VRAR Fish BLM in the EU risk assessment. In a first phase, we developed a de novo gBAM based on the most complete available chronic fish toxicity dataset, i.e. the juvenile rainbow trout dataset of Cremazy et al. (2017). In a second phase, we tested how well this chronic gBAM for juvenile rainbow trout (Oncorhynchus mykiss) performed in terms of toxicity predictions to other fish species, endpoints and life-stages.

This article is protected by copyright. All rights reserved. 


\section{MATERIALS AND METHODS}

\section{Selection of fish Cu bioavailability datasets}

For the purpose of bioavailability modelling, we only selected studies in which copper toxicity was tested in at least two media with different chemistries. More chronic fish toxicity studies are certainly available, but bioavailability relationships can only be reliably inferred from comparative toxicity tests run in parallel in the same laboratory. Otherwise, it is not possible to differentiate a bioavailability effect of any given water chemistry variable from mere interlaboratory variability. Because of a lack of true chronic bioavailability studies with fish (i.e. test duration encompassing a significant portion of the organism's life-cycle), it is accepted to consider early-life stage tests and growth experiments with larval and juvenile fish as equivalent to chronic (ECHA 2017). It has been demonstrated that short-term chronic studies on fathead minnow (Pimephales promelas) following USEPA methods (USEPA 2002) are a good proxy for longer term tests (Norberg \& Mount, 1985). We considered all reported exposure durations but required that organisms were fed during the tests.

A total of 5 studies were retained for the current analysis. These included two studies in which the effects of water chemistry on 30d-Cu toxicity to juvenile rainbow trout was investigated (Waiwood \& Beamish 1978a,b; Cremazy et al. 2017). In addition, three early-life stages tests were identified, i.e. two 7d-larval fathead minnow tests (Erickson et al. 1996; OSU 2016a) and a 52-day ELS test with rainbow trout (fertilized embryo at test initiation; OSU 2016b). Tests with juveniles conduct exposure of life-stages that have not yet reached sexual maturity but that have already developed dorsal and caudal fins

This article is protected by copyright. All rights reserved. 
(Embry et al. 2010; OECD 2019), while early-life stage tests consider exposures of fertilized eggs, embryos and larvae (Embry et al. 2010; OECD 2013). A summary of characteristics per study is given in Table 1. A more detailed description of each dataset and its uncertainties in terms of effect value estimation and physico-chemistry used for bioavailability modelling is given in Supplemental Information (S1).

The toxicity dataset of Cremazy et al. (2017) is the most detailed in describing $\mathrm{Cu}$ bioavailability relations, as the univariate effects of $\mathrm{pH}, \mathrm{Ca}, \mathrm{Mg}$, and $\mathrm{DOC}$ on survival were reported. Hence, this dataset was deemed to be the most appropriate to develop the actual gBAM. In addition, it is also the most reliable dataset in terms of LCx estimates and speciation calculations (because availability of measured DOC values). Cremazy et al. (2017) also measured the effects of water-chemistry on copper toxicity on growth of juvenile rainbow trout. However, no growth effects of copper were observed. Therefore, only the survival-endpoint was used to parametrize the chronic $\mathrm{Cu}$ gBAM for fish. The juvenile rainbow trout data of Waiwood \& Beamish (1978 a,b) were used to analyze the ability to extrapolate the developed gBAM across datasets. The early life stages data (Erickson et al. 1996; OSU 2016a,b) were used to evaluate if the juvenile rainbow trout gBAM can be extrapolated to other fish species (fathead minnow), life-stages, (early-life stages) and endpoints (growth).

Development of a chronic gBAM for juvenile rainbow trout

The gBAM combines assumed competition between $\mathrm{Cu}^{2+}$ and competing ions $\left(\mathrm{Ca}^{2+}\right.$, $\mathrm{Mg}^{2+}$ and $\mathrm{Na}^{+}$) for an assumed single unidentate biotic ligand site with an empirical loglinear $\mathrm{pH}$ effect on the toxicity expressed as free $\mathrm{Cu}^{2+}$ ion activity. The general form of

This article is protected by copyright. All rights reserved. 
the Cu gBAM, expressed based on the $\mathrm{x} \%$ lethal concentration (LCx), is given in equation 1 (Van Regenmortel et al. 2015).

$$
\begin{array}{r}
L C x_{\text {predicted } i, C u^{2+}}=10^{\left(Q x+S_{p H} \times p H_{i}\right)} \times\left[1+K_{N a B L} \times\left(\mathrm{Na}^{+}\right)_{i}+K_{C a B L} \times\left(\mathrm{Ca}^{2+}\right)_{i}+\right. \\
\left.K_{M g B L} \times\left(\mathrm{Mg}^{2+}\right)_{i}\right](\text { Eq. 1) }
\end{array}
$$

The generalized bioavailability model (gBAM), predicts the $\mathrm{x} \%$ lethal concentration (expressed as free $\mathrm{Cu}^{2+}$ ion activity) in water $i\left(\mathrm{LCx}_{\text {predicted } \mathrm{i}, \mathrm{Cu2}+} ; \mathrm{mol} / \mathrm{L}\right)$ as a function of the intrinsic sensitivity $\left(\mathrm{Qx} ; \log _{10}(\mathrm{~mol} / \mathrm{L})\right)$, the $\mathrm{pH}$ slope parameter $\left(\mathrm{S}_{\mathrm{pH}} ; 1 / \mathrm{pH}\right.$ unit), $\mathrm{pH}_{\mathrm{i}}$ in water $i$, the conventional BLM-type single-site biotic ligand competition constants $\left(\mathrm{K}_{\mathrm{CaBL}}, \mathrm{K}_{\mathrm{MgBL}}\right.$ and $\left.\mathrm{K}_{\mathrm{NaBL}} ; \mathrm{L} / \mathrm{mol}\right)$ and the free ion activities of $\mathrm{Ca}^{2+}, \mathrm{Mg}^{2+}$ and $\mathrm{Na}^{+}$ $(\mathrm{mol} / \mathrm{L})$ in water $i$. In the gBAM, it is assumed that the effect of $\mathrm{pH}$ does not interact with the effect of the competing ions, hence, the multiplication in equation 1.

In a first phase, the juvenile RT gBAM was parametrized based on the dataset of Cremazy et al. (2017) reporting 30d-Cu toxicity (mortality) to juvenile RT. For the development of the gBAM, 30d-50\% lethal concentrations (LC50), expressed as dissolved $\mathrm{Cu}$ toxicity were first converted to $\mathrm{Cu}^{2+}$ ion activity using WHAM VII (as specified in the section Speciation modelling). Unfortunately, the $\mathrm{K}_{\mathrm{NaBL}}$ could not be estimated from the existing data, because, to our knowledge, the univariate effects of $\mathrm{Na}$ on Cu toxicity to juvenile RT have not yet been investigated. However, it is very well documented that copper affects Na homeostasis in fish, both in early life stages as in juvenile stages, and, hence, Na provides protection against $\mathrm{Cu}^{2+}$ toxicity (Erickson et al. 1996, Grosell et al. 2012; discussed in more detail in the section Results and discussion Development of the juvenile rainbow trout $g B A M$ ). Therefore, we fixed $\mathrm{K}_{\mathrm{NaBL}}$ to the This article is protected by copyright. All rights reserved. 
value proposed by Cremazy et al. (2017), which originated from the original acute $\mathrm{Cu}$ BLM for larval fathead minnow (Santore et al. 2001), i.e. $\log \mathrm{K}_{\mathrm{NaBL}}=3.0$.

The optimal parameter estimates for the four gBAM parameters (i.e. Qx, $\mathrm{S}_{\mathrm{pH}}, \mathrm{K}_{\mathrm{CaBL}}$, $\mathrm{K}_{\mathrm{MgBL}}$ ) were then estimated using a Markov Chain Monte Carlo algorithm sampling 50 000 parameter sets and minimizing the prediction error on the $\log _{10}\left(\mathrm{LC} 50_{\mathrm{Cu} 2+}\right)$ over all 13 waters considered for gBAM parameter fitting, i.e. the parameter set resulting in the lowest sum of squared errors on $\log _{10}\left(\mathrm{LC} 0_{\mathrm{Cu} 2+}\right)$ (the code used for parameter estimation is included as Supplemental Code). Sampling was performed in the software package R version 3.5.1 using the 'adaptMCMC'-package (Scheidegger et al. 2018). Samples of the four gBAM parameters to be estimated were taken from a normal distribution defined by a mean and standard deviation as follows: for the $\mathrm{S}_{\mathrm{pH}}$-parameter, the slope of the negative linear regression between $\log _{10}\left(\mathrm{LC} 50\right.$ as $\left.\mathrm{Cu}^{2+}\right)$ and $\mathrm{pH}$ was used as a starting parameter value (Figure 1). For $\mathrm{K}_{\mathrm{CaBL}}$ and $\mathrm{K}_{\mathrm{MgBL}}$, the parameter values of the chronic juvenile $\mathrm{RT}$ BLM of Cremazy et al. (2017) were used as starting values (i.e. 10000 and 2 512, respectively, reported in Table 3 in Cremazy et al (2017)). The starting value for Qx was calculated by rearranging Equation 1 to Equation 2, and solving Equation 2 using the starting values of $\mathrm{K}_{\mathrm{CaBL}}, \mathrm{K}_{\mathrm{MgBL}}$ and $\mathrm{S}_{\mathrm{pH}}$.

$$
\begin{aligned}
& Q_{x} \\
& =\frac{\sum_{i}^{n}\left(\log \left(\frac{L C x_{\text {observed } i, C u^{2+}}}{\left(1+K_{N a B L} \times\left(N a^{+}\right)_{i}+K_{C a B L} \times\left(C a^{2+}\right)_{i}+K_{M g B L} \times\left(M g^{2+}\right)_{i}\right)}\right)-S_{p H} \times p H_{i}\right)}{n}
\end{aligned}
$$

This article is protected by copyright. All rights reserved. 
In Equation 2, $\mathrm{LCx}_{\text {observed } \mathrm{i,Cu2}+}$ is the free $\mathrm{Cu}^{2+}$ activity at $\mathrm{LCx}$ in test solution $i$ and $n$ is the number of test solutions considered. A standard deviation of $20 \%$ of these starting values was selected. Using the final parameter set selected by the MCMC-algorithm, $\mathrm{Cu}$ sensitivity of RT can be predicted in any type of water based on measured physicochemistry using Equation 1 (Fitting curves for the MCMC-estimated parameters are shown in Supplementary Information; Figure S1.1).

Validation of the chronic gBAM for juvenile rainbow trout

In a second phase, the juvenile rainbow trout survival data of Waiwood \& Beamish (1978 a,b) was used to validate the developed gBAM across datasets, while early life stages data (Erickson et al. 1996; OSU 2016a,b) was used to evaluate if the juvenile rainbow trout gBAM can be extrapolated to other fish species (fathead minnow), life-stages (early life-stages) and other endpoints (growth). Differences in Cu sensitivity between datasets as a result of differences in effect levels, species, life-stages, exposure durations, endpoints and inter-laboratory variability were accounted for by the gBAM by calibrating the intrinsic sensitivity parameter $(\mathrm{Qx})$ on each dataset and endpoint separately using Equation 2, while keeping all other parameters constant. $\mathrm{Cu}^{2+}$ toxicities (LCx or ECx) were then predicted with Eq. 1, using the latter recalibrated intrinsic sensitivity and test water-specific physico-chemistry, while again keeping all other parameters constant. In a final step, predicted dissolved $\mathrm{Cu}$ toxicities were calculated by translating the $\mathrm{Cu}^{2+}$ toxicities predicted with Equation 1 using WHAM VII. The performance of the juvenile rainbow trout gBAM was evaluated by comparing the gBAM-predicted dissolved $\mathrm{Cu}$ toxicities with the observed toxicities. To assess the performance of the newly-developed juvenile RT gBAM relative to the pre-existing BLMs, Cu toxicity predictions were also This article is protected by copyright. All rights reserved. 
made using the chronic juvenile RT BLM of Cremazy et al. (2017) based on speciation calculations in Visual Minteq and the Cu VRAR Fish BLM using speciation calculations in WHAM V (ECI 2008). Bioavailability modelling for these BLMs are explained in more detail in Supplemental Information (section S2).

\section{Speciation modelling}

We assumed that equilibrium copper speciation was attained in all exposure media. This is experimentally supported by data for the OSU (2016a,b; 2017) studies, but not for Cremazy et al. (2017) and Waiwood and Beamish (1978a,b). In the study of Cremazy et al. (2017) residence time in the flow-through exposure chambers was 80 minutes, although total equilibration time might have been longer as the time of equilibration in the mixing chambers has not been specified. Hence, it is unclear if equilibrium speciation was entirely reached in the exposure medium in the study of Cremazy et al. (2017). This is because it has been reported that up to $30 \mathrm{~h}$ are required to reach equilibrium in exposure media, especially at high DOC (Ma et al. 1999). With a residence time of around $11 \mathrm{~h}$ and the low DOC concentrations in the Waiwood and Beamish study (1978b), the non-equilibrium-reaching appears to be less of an issue for the Waiwood and Beamish toxicity data. The assumption on equilibrium speciation is not an issue for Erickson et al. (1996) as $\mathrm{Cu}^{2+}$ activity was measured using an ion-selective electrode, enabling us to work directly with measured $\mathrm{Cu}^{2+}$ activities.

For all other studies, equilibrium speciation calculations were performed in WHAM VII software (NERC, 2011; Tipping et al. 2011), using default settings and default thermodynamic databases of binding constants (except for copper inorganic complexing),

This article is protected by copyright. All rights reserved. 
with following assumptions: (I) NIST constants were used for inorganic complexing of copper (see Table S2.2 in Supplemental Information); (II) Activity of $\mathrm{Fe}^{3+}$ was assumed to be under control of colloidal $\mathrm{Fe}(\mathrm{OH})_{3}$, and was calculated from $\mathrm{pH}$, following the default function in WHAM VII software. In addition, it was assumed that DOM (from natural sources in all considered studies) contains 50\% carbon on weight basis and consists of $65 \%$ active fulvic acid. Hence, the fulvic acid (FA) input in the speciation model was calculated as follows: FA $=1.3$ x DOC (Bryan et al. 2002). Cremazy et al. (2017) used the same assumption on organic $\mathrm{Cu}$-complexation for modelling $\mathrm{Cu}$ speciation in Visual Minteq, while different assumptions were used for modelling $\mathrm{Cu}$ speciation with the Cu VRAR Fish BLM in WHAM V. A detailed overview of the assumptions used for bioavailability modelling in the present study, in Cremazy et al. (2017) and for the Cu VRAR is given in Supplemental Information (Table S2.2).

\section{RESULTS \& DISCUSSION}

\section{Development of the juvenile rainbow trout gBAM}

The evaluation of how toxicity at the level of free $\mathrm{Cu}^{2+}$ ion activity changes as a function of water chemistry variables, allows to discriminate between speciation effects of water chemistry (i.e., complexation with DOC and inorganic ligands) and effects on the organism (e.g. competitive uptake, physiological effects) (Di Toro et al. 2001). Figure 1 shows the univariate relationship between $\log \mathrm{Cu}^{2+}$ toxicity and $\mathrm{pH}$. Considerable variation of 30d-Cu ${ }^{2+}$ ion toxicity on survival is observed across the different $\mathrm{pH}$ levels in the Cremazy et al. (2017) dataset, i.e. up to 2-orders of magnitude (Figure 1). A negative linear-relation is observed between the logarithm of the $\mathrm{Cu}^{2+} \mathrm{LCx}$ and $\mathrm{pH}$, implying that

This article is protected by copyright. All rights reserved. 
$\mathrm{Cu}^{2+}$ toxicity increases with increasing $\mathrm{pH}$. The negative relationship observed between $\mathrm{pH}$ and the $\mathrm{Cu}^{2+} \mathrm{LCx}$ could be explained by competitive binding of $\mathrm{H}^{+}$-ions at the uptake site which affords protection against $\mathrm{Cu}^{2+}$ toxicity. Given that the relationship is loglinear also other effects of $\mathrm{pH}$ on $\mathrm{Cu}^{2+}$ toxicity may play a role (see further). The strong log-linear correlations $\left(\mathrm{R}^{2} \geqq 0.96\right)$ between $\mathrm{pH}$ and the logarithm of the $\mathrm{Cu}^{2+} \mathrm{LCx}$ overall supports the gBAM model structure (Equation 1). However, it should be noted that the effect of $\mathrm{pH}$ on the $\log \left(\mathrm{LCx}_{\mathrm{Cu} 2+}\right)$ levels off at high $\mathrm{pH}$, i.e. there is no change of $\mathrm{LCx}_{\mathrm{Cu} 2+}$ at the two highest $\mathrm{pH}$ levels. The latter may suggest that two different mechanisms by which $\mathrm{pH}$ is affecting $\mathrm{Cu}^{2+}$ toxicity are acting at the same time. $\mathrm{S}_{\mathrm{pH}}$ values were relatively similar among different effect levels in the $\mathrm{pH}$ series of the Cremazy et al. (2017) dataset. The resulting $\mathrm{S}_{\mathrm{pH}}$ values ranged between -0.403 and -0.466 , depending on the considered effect level. The pH-slope of 30d-LC50 values was used as starting parameter for the calculations of the gBAM parameters.

Cremazy et al. (2017) reported strong positive linear relations between $\mathrm{Cu}^{2+}$ activities (30d-LC50) and $\mathrm{Ca}^{2+}$ and $\mathrm{Mg}^{2+}$ activities. This indicates that $\mathrm{Ca}^{2+}$ and $\mathrm{Mg}^{2+}$ both protect against $\mathrm{Cu}^{2+}$ toxicity, which can be explained using the BLM and the gBAM framework by competitive inhibition of binding of $\mathrm{Cu}^{2+}$ to the biotic ligand sites by $\mathrm{Ca}^{2+}$ and $\mathrm{Mg}^{2+}$ ions (De Schamphelaere et al. 2004; Deleebeeck et al. 2007). Biotic ligand constants of 4.0 for $\mathrm{Ca}$ (expressed as $\log \mathrm{K}_{\mathrm{CaBL}}$ ) and 3.4 for $\mathrm{Mg}\left(\log \mathrm{K}_{\mathrm{MgBL}}\right)$ have previously been reported by Cremazy et al. (2017). The latter values were used as starting values for parameter fitting in the present study. Hence, the following gBAM parameter set was used as starting point for fitting of the gBAM parameters: for $\mathrm{S}_{\mathrm{pH}}-0.466$, for $\mathrm{K}_{\mathrm{CaBL}} 10$ 000, for $\mathrm{K}_{\mathrm{MgBL}} 2512$ and for Q50 -5.06. The resulting best-fitting parameter (i.e. lowest

This article is protected by copyright. All rights reserved. 
sum of squared errors) set was the following: for $\mathrm{S}_{\mathrm{pH}}-0.449$; for $\mathrm{K}_{\mathrm{CaBL}} 9695$; for $\mathrm{K}_{\mathrm{MgBL}}$ 2428 and for Q50 5.14.

A $K_{\mathrm{NaBL}}$ could not be derived from the Cremazy et al. (2017) study, because the Na effect on $\mathrm{Cu}$ toxicity was not investigated. To our knowledge, there are also no other data available that document the effect of $\mathrm{Na}$ on chronic toxicity to juvenile rainbow trout. However, it is very well documented that copper affects Na homeostasis uptake in fish, both in early life stages as in juvenile stages. During short-term exposures, it has been shown that low $\mathrm{Cu}$ concentration reduce $\mathrm{Na}^{+}$uptake. At higher $\mathrm{Cu}$ concentrations, Naplasma levels are also influenced via increased loss due to an increased cell membrane permeability because $\mathrm{Cu}$ displaces $\mathrm{Ca}$ in the tight junction proteins (reviewed by Grosell 2012). In addition, the protective effects of Na on acute and chronic toxicity to Daphnia magna (De Schamphelaere \& Janssen 2002; 2004), and on 7d-survival and growth of larval fathead minnow (Erickson et al. 1996) have been clearly demonstrated.

Given the ample evidence from mechanistic studies on $\mathrm{Cu}$ interacting with $\mathrm{Na}$ homeostasis, it is, in our opinion, reasonable to assume that the protective effect of $\mathrm{Na}$ on chronic copper toxicity is common to most freshwater organisms, and most certainly for fish. Therefore, it seemed reasonable, and more likely to match with reality, to also include a biotic ligand binding competition constant for $\mathrm{Na}$ in the chronic copper gBAM for fish. In the absence of data to estimate a $\log \mathrm{K}_{\mathrm{NaBL}}$ for chronic copper toxicity to juvenile rainbow trout, we could not estimate the best fitting parameter in a similar way as for $\mathrm{K}_{\mathrm{CaBL}}$ and $\mathrm{K}_{\mathrm{MgBL}}$. Instead, we fixed $\mathrm{K}_{\mathrm{NaBL}}$ to the value proposed by Cremazy et al. (2017), which originated from the original acute Cu BLM for larval fathead minnow (Santore et al. 2001), i.e. $\log \mathrm{K}_{\mathrm{NaBL}}=3.0$. The latter value is within the range of estimates This article is protected by copyright. All rights reserved. 
for larval fathead minnow (i.e., 2.7-3.5 derived in the present study based on the larval fathead minnow survival-data of Erickson et al. (1996), Figure S3.1 in Supplemental Information). In addition, this $\log \mathrm{K}_{\mathrm{NaBL}}$ is also relatively close to the $\log \mathrm{K}_{\mathrm{NaBL}}$ of the chronic D. magna BLM (i.e., 2.9, De Schamphelaere and Janssen, 2004) and the log $\mathrm{K}_{\mathrm{NaBL}}$ of the chronic D. magna gBAM (i.e., 2.7, Van Regenmortel et al. 2014).

The resulting predicted univariate bioavailability effects on free $\mathrm{Cu}^{2+}$ toxicity (30d-LC50) are plotted in Figure 2. Overall, these closely match the observed effects of bioavailability on $\mathrm{Cu}^{2+}$ toxicity. Although the data did not show a decrease in $\log \left(\mathrm{LCx}_{\mathrm{Cu2}^{+}}\right)$between $\mathrm{pH} 7.9$ and 8.5, the model predicts due to its log-linear nature a slight $\mathrm{pH}$ effect between $\mathrm{pH} 7.9$ and 8.5. This results in an underestimation of $\mathrm{Cu}^{2+}$ toxicity at $\mathrm{pH} 7.9$ (i.e. 2.1-fold overestimation of $\mathrm{LCx}_{\mathrm{Cu2}+}$ ), while $\mathrm{Cu}^{2+}$ toxicity at $\mathrm{pH} 8.5$ is accurately predicted (i.e. no under or overestimation of $\mathrm{LCx}_{\mathrm{Cu2}+}$ ). Although these prediction errors are relatively small, they suggest that extrapolating the juvenile RT gBAM above $\mathrm{pH} 8.5$ should be avoided.

An overview of the final parameter values included in the chronic Cu gBAM for juvenile rainbow trout and a comparison with the existing chronic fish BLMs is given in Table 2. The log-linear pH effect in the newly developed gBAM for juvenile rainbow trout (parametrized via $\mathrm{S}_{\mathrm{pH}}$ ) is assumed to integrate in a non-mechanistic manner all possible mechanisms by which $\mathrm{pH}$ can affect the toxicity expressed as the free $\mathrm{Cu}^{2+}$ ion activity (Mebane et al. 2020). These can, next to the competition between $\mathrm{H}^{+}$and $\mathrm{Cu}^{2+}$ at the biotic ligand sites, also include the potential toxicity contribution of complexes like $\mathrm{CuOH}^{+}$and $\mathrm{CuCO}_{3}$ (Erickson et al. 1996; Grosell et al. 2004), influences of $\mathrm{pH}$ on the membrane permeability (Lavoie et al. 2012), and/or differences between bulk pH and gill This article is protected by copyright. All rights reserved. 
microenvironment $\mathrm{pH}$ and mucus production which exert a buffering effect on $\mathrm{Cu}^{2+}$ ion activities in the gill microenvironment (Tao et al. 2002).

By integrating the effect of $\mathrm{pH}$ as a $\mathrm{pH}$ slope, a reduction of 2 to 3 model parameters compared to pre-existing chronic Cu BLMs for fish (De Schamphelaere et al. 2008; Cremazy et al. 2017) is obtained in the chronic gBAM for juvenile rainbow trout. This is because in the $\mathrm{Cu}$ VRAR Fish BLM and in the chronic juvenile RT BLM these combined effects of $\mathrm{pH}$ on $\mathrm{Cu}^{2+}$ toxicity are parametrized by a combination of $\mathrm{K}_{\mathrm{HBL}}, \mathrm{K}_{\mathrm{CuBL}}$, $\mathrm{K}_{\mathrm{CuOHBL}}$ and/or $\mathrm{K}_{\mathrm{CuCO} B \mathrm{BL}}$ The biotic ligand competition constants for both $\mathrm{Mg}$ and Ca derived in the present study are the same as those derived by Cremazy et al. (2017). Compared to the $\mathrm{Cu}$ VRAR Fish BLM, the Ca biotic ligand constant of the Fish gBAM is slightly higher, while the Mg biotic ligand constant is relatively similar. Overall, this suggests that the effect of $\mathrm{Ca}$ is more important in protecting against chronic toxicity to juvenile RT compared to acute toxicity of D. magna.

\section{Comparison of model performance with existing BLMs}

In a first step of evaluating the prediction performance of the newly developed gBAM for juvenile rainbow trout, we analyzed the ability of the gBAM to predict the univariate effects observed in the Cremazy et al. (2017) toxicity dataset on which the gBAM has been developed (i.e. autovalidation; Garman et al. 2020). The prediction performance of the gBAM was evaluated based on 30d-LC10, 30d-LC20 and 30d-LC50. The prediction performance was compared relative to the prediction performances of the existing fish BLMs, i.e. the chronic juvenile RT BLM (Cremazy et al. 2017) and the Cu VRAR Fish BLM (De Schamphelaere \& Janssen 2008). The results of this evaluation are presented in 
Figure 3 for the 30d-LC50 values, while 30d-LC10 and 30d-LC20 predictions are presented in Supplemental Information (Figure S2.1). The calibrated average intrinsic sensitivity values of the juvenile RT gBAM for the Cremazy et al. (2017) dataset were 5.48 (30d-Q10), -5.35 (30d-Q20) and -5.14 (30d-Q50). Hence, the lower the intrinsic sensitivity parameter of the juvenile RT gBAM, the higher the $\mathrm{Cu}^{2+}$ sensitivity is (i.e. lower LCx). Intrinsic sensitivities for the fish BLMs are given in Supplemental Information (Table S2.1). Using these intrinsic sensitivities, the gBAM for juvenile rainbow trout predicted observed 30d- LC10, 30d-LC20 and 30d-LC50 values with a median error of 1.3-fold, 1.2-fold and 1.1-fold, respectively (Figure 3, Figure S2.1).

The direction and the magnitude of the effects of $\mathrm{pH}, \mathrm{DOC}, \mathrm{Mg}$ and $\mathrm{Ca}$ (as observed in the 3 'univariate test series'; data points in Figure 3) were well reflected by the predictions (Figure 3, full lines). The observed and predicted DOC effect are almost identical, which suggests that our assumption of equilibrium speciation (despite relatively short equilibration time), combined with the $65 \%$ active fulvic assumption was appropriate for predicting the magnitude of the DOC effect on copper speciation and toxicity. The pH effect is also well captured by the gBAM, without any obvious bias. In addition, the observed decrease of dissolved $\mathrm{Cu}$ toxicity as a function of increasing $\mathrm{Mg}$ and $\mathrm{Ca}$ is also predicted by the juvenile RT gBAM, although the trend is more accurately reflected for the 30d-LC50 data (i.e. the data on which the gBAM parameters have been calibrated) than for the 30d-LC20 and 30d-LC10 data.

Median prediction errors of the juvenile RT BLM and the Cu VRAR Fish BLM for the Cremazy et al. (2017) LCx data were 1.3-1.4-fold and 1.4-1.5-fold, respectively, which is similar or (slightly) higher than the prediction errors of our gBAM (1.1-1.3-fold; Table This article is protected by copyright. All rights reserved. 
S2.3). The gBAM predicts especially the $\mathrm{pH}$ effect more accurately compared to both BLMs (i.e. lowest median prediction errors for the $\mathrm{pH}$ series; Table S2.3). More specifically, the chronic juvenile RT BLM developed by Cremazy et al. (2017) shows a tendency to overestimate 30d-LCx values at pH >8 (especially for LC20 and LC50s; Figure S2.1), while the Cu VRAR Fish BLM underestimates 30d-LCx at $\mathrm{pH}<6$. In addition, the $\mathrm{Cu}$ VRAR Fish BLM underestimates the effect of $\mathrm{Ca}$ on dissolved $\mathrm{Cu}$ toxicity compared to both the chronic juvenile RT BLM and the juvenile RT gBAM. On the other hand, the $\mathrm{Cu}$ VRAR Fish BLM predicts the trend of decreasing Cu toxicity as a function of increasing Mg concentrations more accurate compared to the juvenile RT models. Overall, we conclude that the gBAM performs slightly better than the existing BLMs to explain the effects of water chemistry, notably $\mathrm{pH}$, on chronic copper toxicity to juvenile rainbow trout.

\section{Validation of the juvenile rainbow trout gBAM}

We further validated the chronic gBAM for juvenile rainbow trout with the only additional dataset that reported semi-chronic toxicity (30d) to juvenile rainbow trout. Rather than using the intrinsic sensitivity of the Cremazy et al. (2017) dataset for predictions of Cu toxicity in the Waiwood \& Beamish (1978a,b) dataset as was done in the validation of the chronic juvenile RT BLM for this dataset (Cremazy et al. 2017), the intrinsic sensitivity parameter of the gBAM was specifically calibrated on this dataset (30d-Q20=-4.85) to account for possible differences in Cu sensitivity between laboratory and between test organisms origin and differences in test duration. Although the dataset of Waiwood and Beamish (1978a,b) showed originally a 13-fold variation across the six tested media that varied in $\mathrm{pH}$ (2-levels: $\mathrm{pH} 6.0$ and $\mathrm{pH}$ 7.5-8.0) and hardness (3-levels: This article is protected by copyright. All rights reserved. 
30, 100 and $360 \mathrm{mg} \mathrm{CaCO} / \mathrm{L}$ ), the gBAM was able to explain the observed toxicities with reasonable accuracy. We found a maximum prediction error of 1.6, and a median prediction error of 1.3 (Figure 4). In addition, the observed trend of decreasing toxicity with increasing hardness was very well reflected by the model.

In order to compare the prediction performance of the newly developed gBAM with those of the pre-existing BLMs, we also recalibrated the pre-existing BLMs on the Waiwood and Beamish dataset (see Table S2.2 for sensitivity parameters). With a median prediction error of 1.2 and 1.3, respectively, the chronic juvenile RT BLM developed by Cremazy et al. (2017) and the Cu VRAR Fish BLM (ECI 2008) predicted the observed Cu toxicity in the Waiwood \& Beamish (1978a,b) dataset slightly more accurately or as accurate compared to the gBAM. Especially at low $\mathrm{pH}$ predictions of all bioavailability models are almost identical (Figure 4, left panel). At high pH, the gBAM tends to be slightly less accurate which is shown by the underestimation of $\mathrm{Cu}$ toxicity at high hardness and overestimation of toxicity at low hardness (Figure 4, right panel). However, it should be noted that several factors accompanying this dataset complicate the analysis and may explain the remaining uncertainty. These include the use of slightly extrapolated LC20 values (which were derived 'by eye from log-probit paper', according to the authors, Waiwood and Beamish, 1978b), uncertainty about DOC levels and waterchemistry (which were estimated, see discussion in Supplemental Information), differences in exposure system, and origin of test organisms.

This article is protected by copyright. All rights reserved. 


\section{Cross-life stage and cross-species extrapolation of the gBAM}

In the second study phase, we wanted to explore the performance of the developed juvenile rainbow trout gBAM from a risk assessment perspective. Whilst we acknowledge that differences in bioavailability modifying effects on copper toxicity may exist between different fish species, life stages, endpoints and effect levels (discussed in more detail further in this section), it may - from a regulatory point of view - be more practical to implement a single gBAM (i.e. a single set of parameters) for all fish life stages and endpoints into risk assessment. Hence, the possibility to extrapolate the chronic $\mathrm{Cu}$ gBAM across life stages, fish species and endpoints was evaluated using early life stage data for rainbow trout and fathead minnow (data from OSU [2016a,b]; Erickson et al. [1996]). Therefore, we calibrated the gBAM to each dataset and endpoint independently to account for intrinsic sensitivity differences between life stages, species, studies and endpoints and then made predictions of LCx and ECx values.

The evaluation of the applicability of the gBAM for early life stages of fathead minnow was performed using the data from Erickson et al. (1996) and from OSU (2016a). It should be noted that this evaluation for the Erickson et al. (1996)-dataset is done on the basis of measured free $\mathrm{Cu}^{2+}$ ion. Equilibrium speciation modelling would not work for this dataset, because $\mathrm{Cu}$ was not sufficiently equilibrated with DOM in this study. Hence, because evaluation of the bioavailability model performance for the Erickson et al. (1996)-study is based on free $\mathrm{Cu}^{2+}$ activity, the interpretation of the results of this evaluation are a bit more difficult to relate to a risk assessment viewpoint, as risk assessments are usually performed on a dissolved Cu basis. For the dataset of Erickson et al. (1996), the intrinsic sensitivity was calibrated on all waters, except the $\mathrm{pH} 6.6$ and $\mathrm{pH}$ This article is protected by copyright. All rights reserved. 
7.3 water. In these low $\mathrm{pH}$ waters, $\mathrm{pH}$ had been buffered using $\mathrm{CO}_{2}$ treatment, which may have influenced $\mathrm{Cu}$ toxicity (see below). Calibrated average intrinsic sensitivities for this dataset are $-5.26,-4.84,-5.35$ and -5.38 for the 7d-LC10, 7d-LC60, 7d-EC60 (growth rate) and 7d-EC60 (dry weight), respectively.

Overall, the model predicts the observed $\mathrm{Cu}^{2+}$ toxicities relatively accurately, with $90 \%$ of the $\mathrm{Cu}^{2+}$ toxicity values predicted within 2-fold error (Figure 5; excluding the waters using CO2 treatment). Median prediction errors for the dataset of Erickson et al. (1996) ranged between 1.3 and 1.6, the range representing the different effect levels and endpoints. Within the pH series of the Erickson et al. (1996) dataset, toxicity for the survival endpoint of the lowest $\mathrm{pH}$ treatment ( $\mathrm{pH} 6.6$ buffered using $\mathrm{CO}_{2}$ treatment) was underestimated by the gBAM (open symbols in Figure 5). It has been reported that increased $\mathrm{pCO}_{2}$ of exposure water can increase metal toxicity, most likely because elevated $\mathrm{pCO}_{2}$ immediately depresses the $\mathrm{pH}$ of the internal body fluids of the animal (“respiratory acidosis”) (Esbaugh et al. 2013). However, a similar underestimation of $\mathrm{Cu}^{2+}$ toxicity was not observed for the sub-lethal endpoints, which questions the latter hypothesis. On the other hand, if the $\mathrm{pCO}_{2}$ was not high enough to affect copper toxicity, it could be hypothesized that the different $\mathrm{pH}$ effect on copper toxicity between survival and growth endpoints, is a result of different toxicity pathways leading to effects on survival vs. growth. The latter is supported by evidence that $\mathrm{Cu}$ induced mortality in fish is associated with Na loss (Grosell et al. 2002), and by some limited evidence that growth effects of Cu correlate with tissue and whole-body copper burden (Marr et al. 1996; Hansen et al. 2002). Research in which both Na uptake, Na loss, Cu accumulation, survival and growth are monitored during $\mathrm{Cu}$ exposure at a range of $\mathrm{pH}$ levels (not

This article is protected by copyright. All rights reserved. 
controlled using $\mathrm{pCO}_{2}$ ) would shed more light on this hypothesis. Compared to the previously developed BLMs (De Schamphelaere \& Janssen 2008; Cremazy et al., 2017), the gBAM performed on average slightly better than the Cu VRAR Fish BLM (76\% of toxicity values predicted within 2-fold error and median prediction errors ranging between 1.3 and 1.8) and the chronic juvenile RT BLM ( $86 \%$ of toxicity values predicted within 2-fold error and median prediction errors ranging between 1.4 and 1.8) (Figure S2.2 and Table S2.4).

The calibrated intrinsic sensitivities for the 7d-larval fathead minnow study of OSU

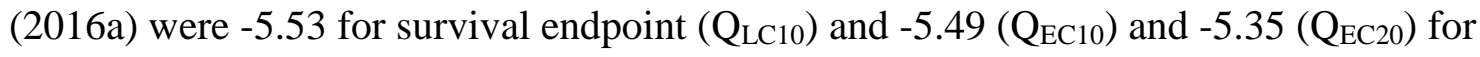
the dry weight endpoint. Since a more negative intrinsic sensitivity value implies a higher sensitivity, the survival endpoint can on average be considered the most sensitive endpoint. Figure 6 shows the capacities of the juvenile rainbow trout gBAM to predict 7d-dissolved Cu toxicity on fathead minnow larval survival (LC10; left panel) and dry weight (EC10; right panel) of the OSU (2016a) data (EC20 plotted in Figure S2.3). The data points of the OSU (2016a)-study were all predicted by the gBAM with a maximum error of 1.5 and a median error of 1.2. Overall, the gBAM predicted the trend of decreasing dissolved $\mathrm{Cu}$ toxicity with increasing pH (Figure 6; Figure S2.3), although the observed slope of the relationship between $\mathrm{pH}$ and dissolved $\mathrm{Cu}$ toxicity appears to be slightly higher than predicted with the gBAM. With median prediction errors of 1.4 to 1.6 (chronic juvenile RT BLM) and 1.2 to 1.3 (Cu VRAR Fish BLM), the pre-existing fish BLMs perform equally good (Cu Fish VRAR BLM) or slightly worse (chronic juvenile RT BLM) compared to the juvenile RT gBAM. Especially the chronic juvenile RT BLM

This article is protected by copyright. All rights reserved. 
overestimates the trend of decreasing dissolved $\mathrm{Cu}$ toxicity with increasing $\mathrm{pH}$ (dashed line in Figure 6).

One additional $\mathrm{Cu}$ bioavailability dataset for early life stages of fish was identified. This study performed by the Oregon State University investigated the effect of $\mathrm{pH}(6.1-7.0)$ on a number of endpoints in a 52d-rainbow trout embryo-larval exposure (OSU 2016b). However, the usefulness of this dataset in evaluating the performance of the juvenile RT gBAM is limited given the limited $\mathrm{pH}$ range tested. In addition, the analysis is also hampered because of the uncertainties on the 42d-LC10 estimation of the $\mathrm{pH} 7.0$ data point as the estimate to our interpretation appears to be an unbounded LC10 rather than the actual LC10, i.e. $\mathrm{LC} 10 \geq 54.2 \mu \mathrm{g} / \mathrm{L}$ at $\mathrm{pH} 7$ (as explained in Supplemental Data S1). Hence, this dataset was not further considered in the present study. The above application of the bioavailability models developed based on juvenile rainbow trout for early life stages of fathead minnow (and rainbow trout), assumes that bioavailability relations can be extrapolated across different life stages, different species and different endpoints. However, this assumption is not necessarily valid. Table S3.1 in Supplemental Information shows an overview of the comparison of bioavailability effects predicted by the gBAM based on toxicity data for juveniles with those observed for the early life stages. Although it should be noted that each of the larval fish datasets suffer from considerable uncertainties, this comparison suggests that there is a tendency for the juvenile rainbow trout gBAM to underestimate the effect of $\mathrm{pH}$. For all larval fish datasets, the slope of the observed effect appears to be (somewhat) stronger than the slope of the predicted effects. For instance, for the Erickson et al. (1996) dataset, the observed effect of a pH change between 8.0 and 8.7 on free $\mathrm{Cu}^{2+}$ ion toxicity for the This article is protected by copyright. All rights reserved. 
mortality endpoint is $\sim 3$-fold, whereas the gBAM predicted effect is only $~ 1.9$-fold (Figure S3.2). Moreover, based on the latter dataset it appears that the $\mathrm{pH}$ slope increases with increasing effect level (Figure S3.2 left panel). In addition, the pH slope of the loglinear relationship between $\mathrm{pH}$ and $\mathrm{Cu}^{2+}$ toxicity might also be dependent on the considered endpoint (Figure S3.2, right panel). For the larval fathead minnow-study of OSU (2016a), there also appears a tendency of a slight underestimation of the strength of the $\mathrm{pH}$ effect between $\mathrm{pH} 5.8$ and 7.0, i.e. an observed 2.2 to 2.4-fold effect vs a predicted 1.6-fold effect (Table S3.1). However, Cu toxicity was not investigated concurrently at the different $\mathrm{pH}$ levels of the latter study and as such the observed effect of pH may have been confounded by between-test temporal variability. Unfortunately, the number and range of $\mathrm{pH}$ levels (with reliable data) in each separate study is rather limited. In order to provide a clearer picture on whether the slope of the $\mathrm{pH}$ effect differs between juvenile and larval fish life stages, it would be worthwhile to investigate in a single study the effect of $\mathrm{pH}$ on dissolved copper toxicity to larval fathead minnows over the entire $\mathrm{pH}$ range in a system in which $\mathrm{Cu}$ is in equilibrium with the DOC and in which no $\mathrm{pCO}_{2}$ is used for $\mathrm{pH}$ control.

A similar evaluation of the capacity of the gBAM for predicting the effects of the competing cations was also performed based on the Erickson et al. (1996) dataset (see Table S3.1). A reliable assessment of the Ca effect is difficult because of less reliable LCx and ECx estimates for the high Ca treatment. The strength of the Mg effect on dry weight is quite accurately predicted, i.e. an observed $\sim 2.0$-fold effect vs a predicted $\sim 1.9$ fold effect (Table S3.1). However, the gBAM shows a tendency to underestimate the Na effect, as the observed effect is $\sim 4-5$-fold, while the predicted effect is only 1.5 -fold

This article is protected by copyright. All rights reserved. 
(Table S3.1). The possible differences in bioavailability relations between early life stages and juvenile fish as observed in the present study, may be explained because early life stages (embryo, alevin \& swim-up larvae) can have vastly different physiology than juvenile fish, including presence/absence of active feeding and ion-regulatory processes. These differences could result in different toxicity mechanisms and pathways between life stages and thus in differences in bioavailability relationships (e.g. if a water chemistry variable affects key physiological processes that have been implicated in copper's toxic mode(s) of action). As such, more targeted experimental work of the effects of water chemistry on Cu toxicity, and by extension on metal toxicity in general, to early life stages of fish could answer whether bioavailability effects on metal toxicity are actually different between early life stages and juveniles of freshwater fish.

The datasets with early life stages are not ideal to draw any strong conclusions (in either directions) on whether or not the juvenile rainbow trout gBAM for chronic copper toxicity can predict the effect of bioavailability on Cu toxicity to early life-stages of fish. Overall, too limited experimental data is available on protective effects of major cations and the effect of $\mathrm{pH}$ on copper toxicity to early life-stages of fish to draw any definitive conclusions on the performance of the gBAM in this respect. Thus, the results of this model extrapolation evaluation in this section should not be overemphasized. However, at the EC10 and LC10, the effect levels most important in European chemical legislative frameworks, $91 \%$ of the individual toxicity data points of fathead minnow early lifestages considered in the present study were predicted within 2-fold error (Figure S2.5). Given that a 2-fold error in predicting the magnitude of the effect of a toxicity modifying factor has been considered acceptable from a regulatory point of view (Di Toro et al.

This article is protected by copyright. All rights reserved. 
2001, Garman et al. 2020), the juvenile RT gBAM performs rather well in predicting Cu toxicity to different life stages of fish. Furthermore, depending on the considered endpoint and effect level it performs at least equally well or slightly better than the existing Fish BLMs.

Conclusions and suggestions for future research

In the present study, based on the Cremazy et al. (2017) dataset a fully parametrized WHAM VII-based chronic Cu gBAM for juvenile rainbow trout was developed as a valuable alternative for the outdated Cu VRAR Fish BLM currently used in environmental threshold derivations in the EU risk assessment frameworks. This newlydeveloped gBAM predicted effects of $\mathrm{pH}, \mathrm{DOC}, \mathrm{Ca}$, and $\mathrm{Mg}$ on chronic $\mathrm{Cu}$ toxicity to juvenile rainbow trout at 30d-LC10 levels relatively accurately with a median prediction error of 1.3-fold. In addition, the log-linear $\mathrm{pH}$ effect incorporated in the newly developed $\mathrm{Cu}$ gBAM predicted the effect of $\mathrm{pH}$ more accurately than the linear BLMtype parametrisations in the pre-existing chronic juvenile RT Cu BLM, especially at $\mathrm{pH}>8$. The $\mathrm{pH}$ range over which the gBAM has been developed and validated, is $\mathrm{pH} 5.0$ to $\mathrm{pH}$ 8.7. Hence, the applicability domain of the newly developed juvenile RT gBAM is slightly wider than the chronic Cu VRAR Fish BLM, which was validated from $\mathrm{pH} 6.0$ to pH 8.7 (De Schamphelaere \& Janssen 2008).

From a regulatory point of view, the implementation of one single bioavailability model for all fish life-stages, fish species and endpoints would be most practical. Therefore, we also analysed how well this single juvenile rainbow trout gBAM predicted toxicity as a function of water chemistry for early life stages of fish and how far model predictions

This article is protected by copyright. All rights reserved. 
deviated from observed toxicity. Given that the datasets with early life stages are not ideal to draw any strong conclusions, the results of this evaluation should not be overemphasized. However, if a 2-fold error in predicting the magnitude of the effect of a toxicity modifying factor is considered acceptable in a regulatory context, the gBAM for juvenile rainbow trout performed rather well for early life stages of fathead minnow. Overall, this suggests that the developed gBAM can be used as an alternative for the existing conventional chronic BLMs for fish.

However, based on the present study, it is recommended to further refine copper bioavailability research with fish. Future research efforts should most preferably include experimental work on the Na effect on chronic $\mathrm{Cu}$ toxicity to juvenile fish and an experimental validation of the gBAM in realistic field-collected waters with juvenile fish. Furthermore, because all available $\mathrm{Cu}$ bioavailability datasets considering early lifestages of fish are accompanied with considerable uncertainties, it is also recommended to further evaluate the effects of water chemistry, e.g. $\mathrm{pH}$, on Cu toxicity to early life-stages of fish.

Supplemental Data-The Supplemental Data are available on the Wiley Online Library at DOI: $10.1002 /$ etc.xxxx.

Acknowledgment-The present study was funded by the European Copper Institute. The authors wish to thank A. Cremazy and C. Wood for reviewing a previous version of this manuscript.

Data accessibility statement_-Data used for bioavailability modelling and code for bioavailability model parameter-estimation can be found in Supplemental Information. This article is protected by copyright. All rights reserved. 


\section{REFERENCES}

Bryan SE, Tipping E, Hamilton-Taylor J. 2002. Comparison of measured and modelled copper binding by natural organic matter in freshwaters. Comp. Biochem. Physiol. C: Toxicol. Pharmacol. 133: 37-49.

Crémazy A, Wood CM, Ng TY, Smith DS, Chowdhury MJ. 2017. Experimentally derived acute and chronic copper Biotic Ligand Models for rainbow trout. Aquat Toxicol.192: 224- 240.

De Schamphelaere KAC, Janssen CR. 2002. A biotic ligand model predicting acute copper toxicity for Daphnia magna: the effects of calcium, magnesium, sodium, potassium, and pH. Environ. Sci. Technol. 36: 48-54.

De Schamphelaere KAC, Janssen CR. 2006. Bioavailability models for predicting copper toxicity to freshwater green microalgae as a function of water chemistry. Environ. Sci. Technol. 40: 4514-4522.

De Schamphelaere KAC, Janssen CR. 2004. Development and field validation of a biotic ligand model predicting chronic copper toxicity to Daphnia magna. Environ.Toxicol. Chem. 23: 1365- 1375.

De Schamphelaere KAC, Janssen CR. 2008. Appendix U: Modelling copper bioavailability and toxicity in freshwater: uncertainty reduction for risk assessment (Chronic fish-BLM). In: European Copper Institute. 2008. European Union risk assessment report: Voluntary risk assessment of copper, copper ii sulphate pentahydrate, copper(i)oxide, copper(ii)oxide, dicopper chloride trihydroxide. ECI, Brussels, Belgium. This article is protected by copyright. All rights reserved. 
Available on: https://echa.europa.eu/nl/copper-voluntary-risk-assessment-reports [Last accessed: February $\left.19^{\text {th }} 2020\right]$

Deleebeeck NME, De Schamphelaere KAC, Janssen CR. 2007. A bioavailability model predicting the toxicity of nickel to rainbow trout (Oncorhynchus mykiss) and fathead minnow (Pimephales promelas) in synthetic and natural waters. Ecotoxicol. Environ. Safe. 67: 1-13.

Di Toro DM, Allen HE, Bergman HL, Meyer JS, Paquin PR, Santore RC. 2001. Biotic ligand model of the acute toxicity of metals. 1. Technical basis. Environ. Toxicol. Chem. 20: 2383-2396.

Embry MR, Belanger SE, Braunbeck TA, Galay-Burgos M, Halder M, Hinton DE, Leonard MA, Lillicrap A, Norberg-King T, Whale G. 2010. The fish embryo toxicity test as an animal alternative method in hazard and risk assessment and scientific research. Aquat. Toxicol. 97: 79-87.

Erickson RJ, Benoit DA, Mattson VR, Nelson HP Jr, Leonard EN. 1996. The effects of water chemistry on the toxicity of copper to fathead minnows. Environ. Toxicol. Chem. 15:181-193.

Esbaugh AJ, Mager EM, Brix KV, Santore R and Grosell M. 2013. Implications of pH manipulation methods for metal toxicity: not all acidic environments are created equal. Aquat. Toxicol. 130-131:27-30.

European Chemicals Agency. 2017. Guidance on the application of the CLP criteria. Version 5.0, Annex I, section I.2.1.2.

This article is protected by copyright. All rights reserved. 
European Commission. 1993. Council Regulation (EEC) 793/93 of 23 March 1993 on the evaluation and control of the environmental risk of existing substances. Official Journal of the European Communities, Brussels, Belgium.

European Commission. 2006. Directive 2013/39/EU of the European Parliament and of the Council of 18 December 2006 amending Council Directive 67/548/EEC on the approximation of laws, regulations and administrative provisions relating to the classification, packaging and labelling of dangerous substances in order to adapt it to Regulation (EC) No 1907/2006 concerning the Registration, Evaluation, Authorisation and Restriction of Chemicals (REACH) and establishing a European Chemicals Agency. Official Journal of the European Communities, Brussels, Belgium.

European Commission. 2013. Directive 2013/39/EU of the European Parliament and of the Council of 12 August 2013 amending Directives 2000/60/EC and 2008/105/EC as regards priority substances in the field of water policy. Official Journal of the European Communities, Brussels, Belgium.

European Copper Institute. 2008. European Union risk assessment report: Voluntary risk assessment of copper, copper ii sulphate pentahydrate, copper(i)oxide, copper(ii)oxide, dicopper chloride trihydroxide. ECI, Brussels, Belgium.

Garman ER, Meyer JS, Bergeron CM, Blewett TA, Clements WH, Elias MC, Farley KJ, Gissi F, Ryan AC. 2020. Validation of bioavailability-based toxicity models for metals. Environ. Toxicol. Chem. 39: 101-117.

This article is protected by copyright. All rights reserved. 
Grosell M, Nielsen C, Bianchini A. 2002. Sodium turnover rate determines sensitivity to acute copper and silver exposure in freshwater animals. Comp. Biochem. Physiol. C: Toxicol. Pharmacol.133: 287-303

Grosell M, McDonald MD, Walsh PJ, Wood CM. 2004. Effects of prolonged copper exposure in the marine gulf toadfish (Opsanus beta). II Drinking rate, copper accumulation and $\mathrm{Na}^{+} / \mathrm{K}^{+}$-ATPase activity in osmoregulatory tissues. Aquat. Toxicol. 68: 263-275.

Grosell M. 2012. Copper. In: Wood CM, Farell AP, Brauner CJ (Eds). Homeostatis and Toxicology of essential metals. Academic Press, London, UK.

Hansen JA, Lipton J, Welsh PG, Morris J, Cacela D, Suedkamp MJ. 2002. Relationship between exposure duration, tissue residues, growth, and mortality in rainbow trout (Oncorhynchus mykiss) juveniles sub-chronically exposed to copper. Aquat. Toxicol. 58: $175-188$

Heijerick D, De Schamphelaere KAC, Van Sprang PA, Jansen CR. 2005. Development of a chronic zinc biotic ligand model for Daphnia magna. Ecotoxicol Environ Safe 62: 1$10 /$

Lavoie M, Le Faucheur S, Boullemant A, Fortin C, Campbell PGC. 2012. The influence of $\mathrm{pH}$ on algal cell membrane permeability and its implications for the uptake of lipophilic metal complexes. J. Phycol. 48:293-302.

This article is protected by copyright. All rights reserved. 
Lofts S, Tipping E. 2011. Assessing WHAM/Model VII against field measurements of free metal ion concentrations: model performance and the role of uncertainty in parameters and inputs. Environ. Chem. 8: 501-516

Ma H, Kim SD, Cha DK, Allen HE. 1999. Effects of kinetics of complexation by humic acid on toxicity of copper to Ceriodaphnia dubia. Environ. Toxicol. Chem. 18:828-837.

Marr JCA, Lipton J, Cacela D, Hansen JA, Bergman HL, Meyer JS, Hogstrand C. 1996. Relationship between copper exposure duration, tissue copper concentration, and rainbow trout growth. Aquat. Toxicol. 36: 17-30.

Mebane CA, Chowdhury MJ, De Schamphelaere KAC, Lofts S, Paquin PR, Santore RC, Wood CM. 2020. Metal bioavailability models: current status, lessons learned, considerations for regulatory use, and the path forward. Environ. Toxicol. Chem. 39: 6084.

NERC. 2011. Windermere Humic Aqueous Model. Version 7.0.0. Equilibrium Chemical Speciation for Waters. Natural Environment Research Council.

Norberg TJ, Mount DI. 1985. A new fathead minnow (Pimephales promelas) subchronic toxicity test. Environ. Toxicol. Chem. 4:711-718.

Nys C, Van Regenmortel T, Jansen CR, Oorts K, Smolders E, De Schamphelaere KAC. 2018. A framework for ecological risk assessment of metal mixtures in aquatic systems. Environ Toxicol Chem 37: 623-642.

This article is protected by copyright. All rights reserved. 
Organization for Economic Co-operation and Development. 2013. Test Guideline No. 210. Fish, Early-life stage Toxicity Test. Guidelines for the testing of chemical, OECD, Paris, France.

Organization for Economic Co-operation and Development. 2019. Test Guideline No. 203. Fish, Acute Toxicity Testing. Guidelines for the testing of chemical, OECD, Paris, France.

OSU. 2016a. Short-term chronic toxicity of copper to the fathead minnow, Pimephales promelas, under varying $\mathrm{pH}$ conditions. Final report. Oregon State University Aquatic Toxicology Laboratory. Prepared for the European Copper Institute. October 2016.

OSU. 2016b. Early life-stage toxicity of copper to the rainbow trout, Oncorhynchus mykiss, under varying pH conditions. Final report. Oregon State University Aquatic Toxicology Laboratory. Prepared for the European Copper Institute. October 2016.

OSU. 2017. Short-term chronic toxicity of copper to the fathead minnow, Pimephales promelas, at a pH of 6. Final report. Oregon State University Aquatic Toxicology Laboratory. Prepared for the European Copper Institute. March 2017.

Rüdel H, Diaz Muniz C, Garelick H, Kandile NG, Miller BW, Pantoja Munoz L, Peijnenburg WGM, Purchase D, Shevah Y, van Sprang P, Vijver M, Vink JPM. 2015. Consideration of the bioavailability of metal/metalloid species in freshwaters: experiences regarding the implementation of biotic ligand model-based approaches in risk assessment frameworks. Environ. Sci. Pollut. Res. 22: 7405-7421.

This article is protected by copyright. All rights reserved. 
Santore RC, Di Toro DM, Paquin PR, Allen HE, Meyer JS. 2001. Biotic ligand model of the acute toxicity of metals. 2. Application to acute copper toxicity in freshwater fish and daphnia. Environ. Toxicol. Chem. 20: 2397-2402.

Scheidegger A. 2018. Package ‘MCMCadapt' v1.3: Implementation of a Generic Adaptive Monte Carlo Markov Chain Sampler. R-package: available on-line: https://cran.r-project.org/web/packages/adaptMCMC/adaptMCMC.pdf [ last accessed: 6 June 2020 ]

Tao S, Long Am, Xu FL, Dawson RW. 2002. Copper speciation in the gill microenvironment of carp (Cyprinus carpio) at various levels of pH. Ecotoxicol. Environ. Safe. 52: 221-226.

Tipping E, Lofts S, Sonke JE. 2011. Humic Ion-Binding Model VII: a revised parameterisation of cation binding by humic substances. Environ Chem. 8(3): 302-325.

USEPA. 2002. Method 1001.0: Fathead minnow, Pimephales promelas, larval survival and teratogenicity test; chronic toxicity. Pg 30.

Van Regenmortel T, Janssen CR, De Schamphelaere KA. 2015. Comparison of the capacity of two biotic ligand models to predict chronic copper toxicity to two Daphnia magna clones and formulation of a generalized bioavailability model. Environ. Toxicol. Chem. 34(7):1597- 608.

This article is protected by copyright. All rights reserved. 
Van Regenmortel T. 2017. Ecotoxicity and risk assessment of metal mixtures in the freshwater environment. Ph D thesis Ghent University, Gent, Belgium. ISBN 9789463570503.

Van Regenmortel T, Janssen CR, De Schamphelaere KA. 2017. Analyzing the capacity of the Daphnia magna and Pseudokirchneriella subcapitata bioavailability models to predict chronic zinc toxicity at high $\mathrm{pH}$ and low calcium concentrations and formulation of a generalized bioavailability model for D. magna. Environ. Toxicol. Chem. 36: 27812798.

Waiwood KG, Beamish FWH. 1978a. The effect of copper, hardness and pH on the growth of rainbow trout, Salmo gairdneri. J. Fish Biol. 13:591-598.

Waiwood KG, Beamish FWH. 1978b. Effects of copper, pH and hardness on the critical swimming performance of rainbow trout (Salmo gairdneri Richardson). Water Res. 12:611-619.

This article is protected by copyright. All rights reserved. 
Figure 1. Effect of $\mathrm{pH}$ on $\log 30 \mathrm{~d}-$ free $\mathrm{Cu}^{2+}$ toxicity for the survival endpoint for various effect levels. Data originated from Cremazy et al. (2017). Free $\mathrm{Cu}^{2+}$ activities were calculated with Windermere Humic Aqueous Model VII.

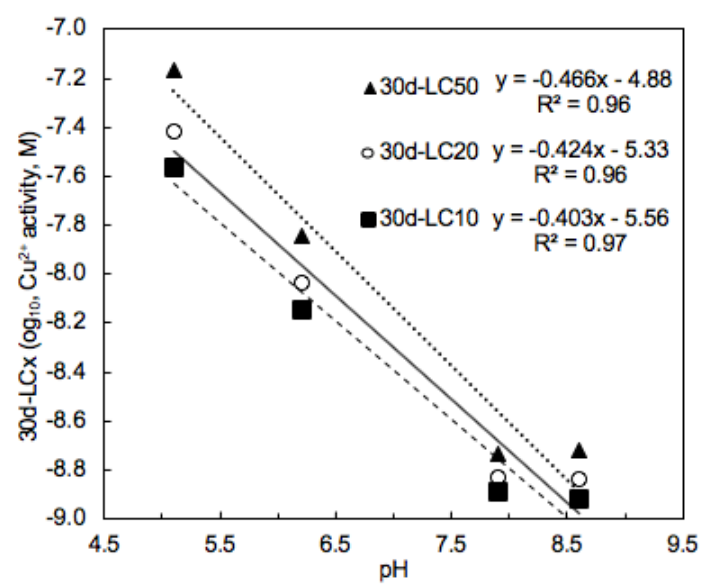

This article is protected by copyright. All rights reserved. 
Figure 2. Observed and predicted effects of $\mathrm{Ca}^{2+}, \mathrm{Mg}^{2+}, \mathrm{pH}$ and DOC on 30d-free $\mathrm{Cu}^{2+}$ toxicity to juvenile rainbow trout (Oncorhynchus mykiss; at the 50\% lethal concentration level; $\left.\mathrm{LC} 50_{\mathrm{Cu} 2+}\right)$. Observed effects are represented by symbols, predictions of the juvenile RT generalized BioAvailability Model (gBAM) are represented by the line. Error bars denote 95\% confidence intervals. Free ion activities were predicted using WHAM VII. Toxicity data originated from Cremazy et al. (2017).
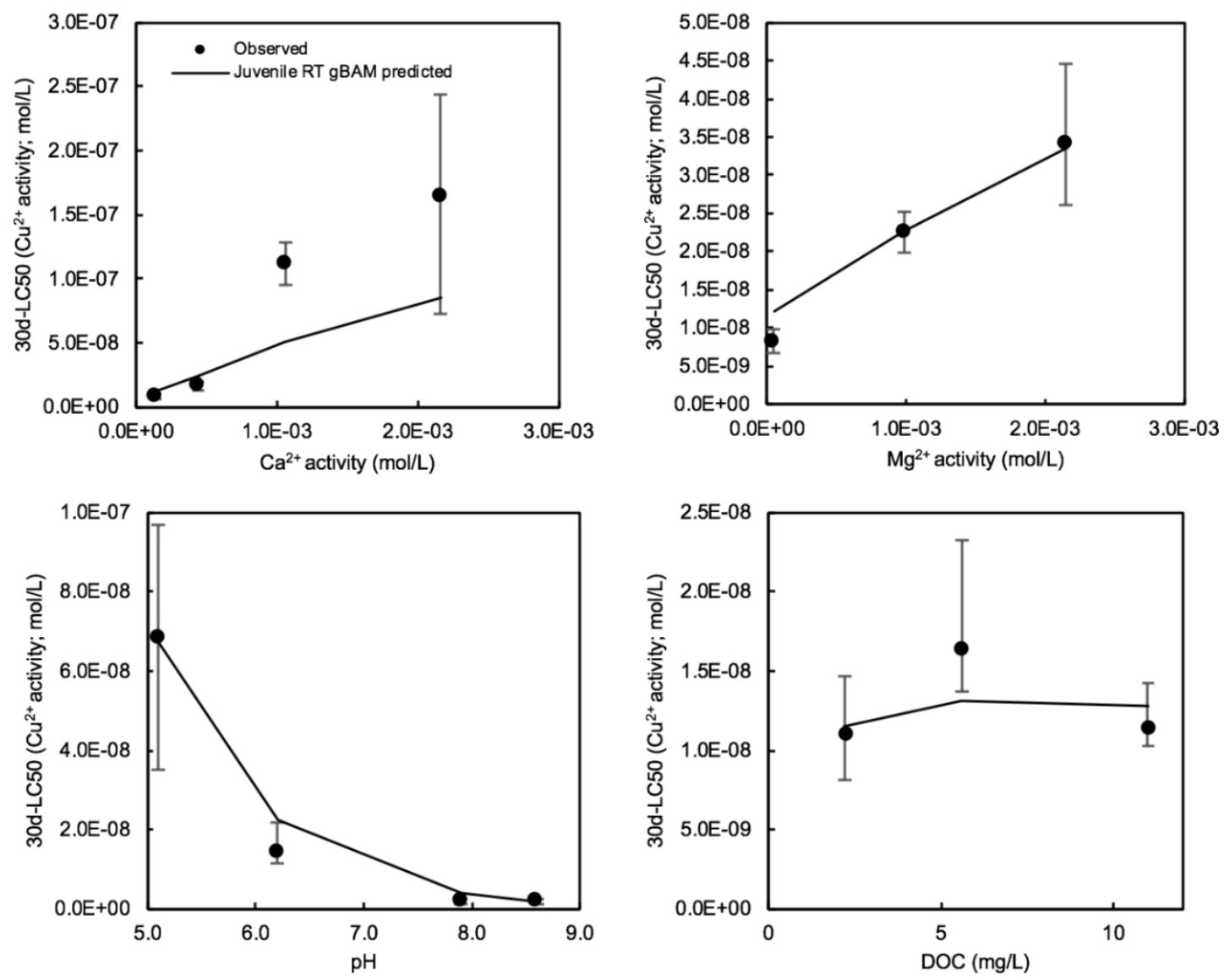

This article is protected by copyright. All rights reserved. 
Figure 3. Predictive capacity of the chronic Cu generalized Bioavailability Model (gBAM) vs. the chronic Cu Fish biotic ligand models (BLM) for 30d-toxicity to juvenile rainbow trout (Oncorhynchus mykiss) as shown by observed vs predicted effects of $\mathrm{pH}$, dissolved organic carbon, Ca and Mg on copper toxicity (30d-LC50; expressed on dissolved $\mathrm{Cu}$ basis). Data points represent observed toxicities. Full line represents the predictions of the chronic $\mathrm{Cu}$ juvenile rainbow trout gBAM developed in the present study. The dashed line represents the predictions of the chronic $\mathrm{Cu}$ juvenile rainbow trout BLM developed by Cremazy et al. (2017), while the dashed-dotted lines represents the predictions of the chronic Cu VRAR (Voluntary Risk Assessment Report) Fish BLM (De Schamphelaere \& Janssen 2008). Error bars denote 95\% confidence intervals. Toxicity data originated from Cremazy et al. (2017).
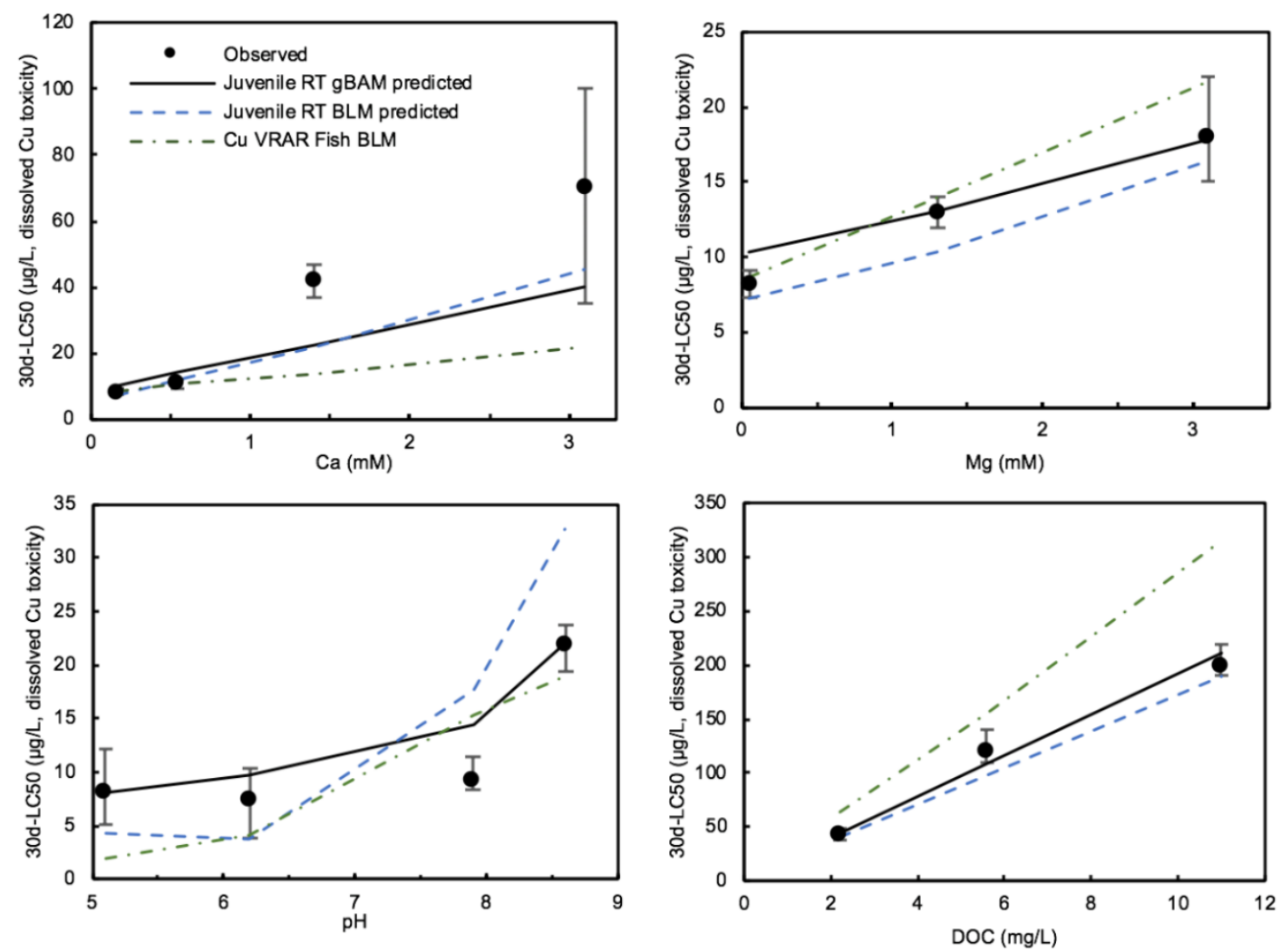

This article is protected by copyright. All rights reserved. 
Figure 4. Performance of the chronic juvenile rainbow trout (RT) gBAM (present study, full line, chronic juvenile RT BLM (Cremazy et al. 2017; dashed line) and Cu VRAR Fish BLM (De Schamphelaere \& Janssen 2008; dotted line) to predict juvenile rainbow trout (Oncorhynchus mykiss) mortality (10d-Cu toxicity; 20\% lethal concentration [LC20]; expressed on dissolved Cu basis). This is presented by showing the effects of hardness on observed (symbols) vs predicted toxicities (lines). Left panel represents toxicity at low $\mathrm{pH}$, right panel represents toxicity at high $\mathrm{pH}$. Toxicity data originated from Waiwood and Beamish (1978a,b).
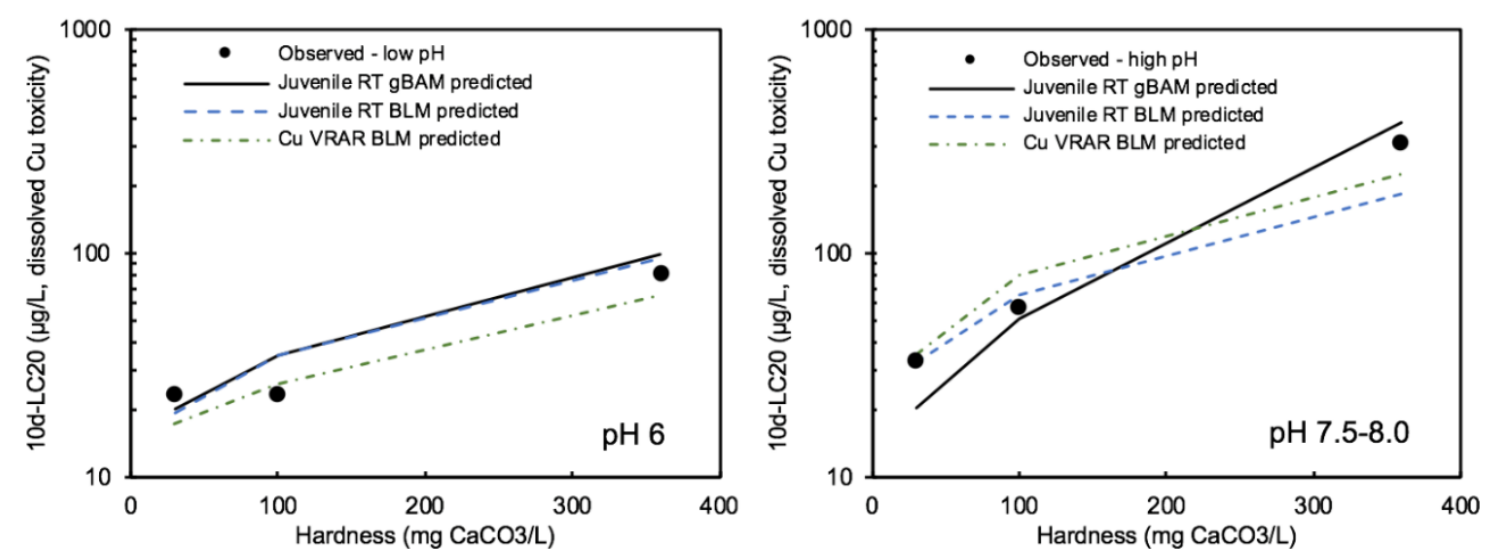

This article is protected by copyright. All rights reserved. 
Figure 5. Predicted versus observed $7 \mathrm{~d}-\mathrm{Cu}^{2+}$ toxicity to early life stages of fathead minnow (Pimephales promelas; expressed as free $\mathrm{Cu}^{2+}$ activity; $\mathrm{nmol} / \mathrm{L}$ ) for the survival endpoint (10\% and 60\% lethal concentration; LC10 [squares] and LC60 [diamonds], respectively), the growth rate endpoint (60\% effect concentration; EC60 [triangles]) and the dry weight endpoint (EC60; [circles]). Predictions were made using the chronic $\mathrm{Cu}$ gBAM for juvenile rainbow trout. The dashed line represents a difference of a factor of two between the observed and predicted data. The full line represents a perfect fit between observed and predicted data. Predictions for waters in which $\mathrm{pH}$ was manipulated via $\mathrm{CO}_{2}$-bubbling are shown as open symbols. Because this treatment may have affected metal sensitivity, these $\mathrm{CO}_{2}$ treated waters have not been used in calculating intrinsic sensitivities and performance statistics. Toxicity data originated from Erickson et al. (1996).

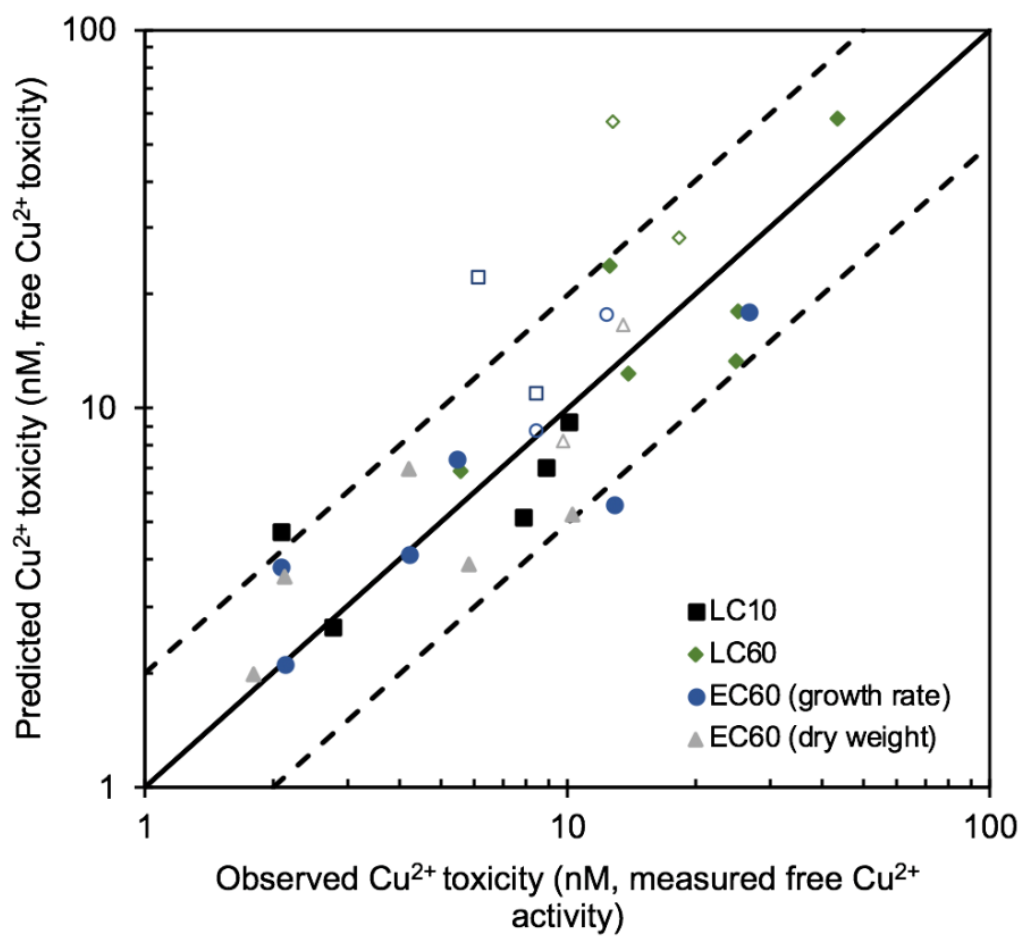

This article is protected by copyright. All rights reserved. 
Figure 6 Performance of the chronic juvenile rainbow trout (RT) gBAM (present study, full line, chronic juvenile RT BLM (Cremazy et al. 2017; dashed line) and Cu VRAR Fish BLM (De Schamphelaere \& Janssen 2008; dotted line) to predict 7d-mortality to larval fathead minnows (Pimephales promelas; 7d-10\% lethal concentration [LC10; left panel] and 7d-10\% effect concentration [EC10, right panel]; expressed on dissolved $\mathrm{Cu}$ basis). This is presented by showing the effects of $\mathrm{pH}$ on observed (symbols) vs predicted toxicities (lines). Toxicity data originated from Oregon State University (2016a).
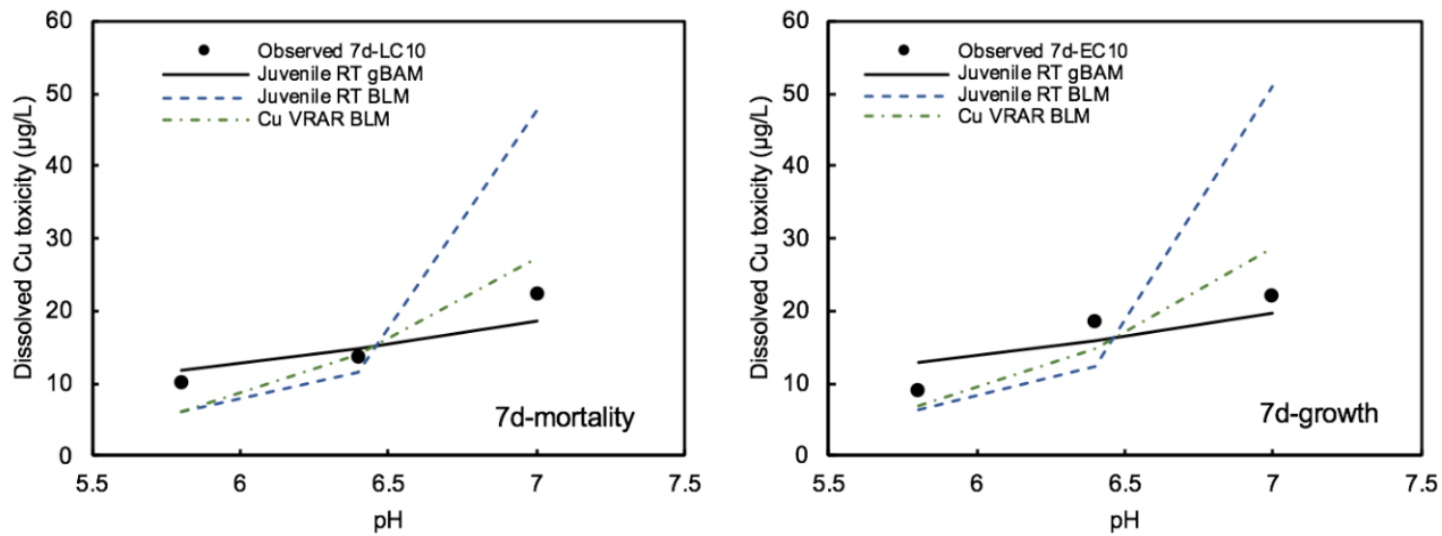

This article is protected by copyright. All rights reserved. 
Table 1. Overview of chronic toxicity studies for rainbow trout (Oncorhynchus mykiss) and fathead minnow (Pimephales promelas) retained for bioavailability modelling

\begin{tabular}{|c|c|c|c|c|c|}
\hline $\begin{array}{l}\text { Study } \\
\text { reference }\end{array}$ & Species & $\begin{array}{l}\text { Life-stage at } \\
\text { test-initiation } \\
\text { (life stage } \\
\text { description) }\end{array}$ & $\begin{array}{l}\text { Test } \\
\text { duration }\end{array}$ & $\begin{array}{l}\text { Endpoint } \\
\text { used for } \\
\text { bioavailability } \\
\text { modelling }\end{array}$ & $\begin{array}{l}\text { Water chemistry } \\
\text { ranges } \\
\text { (number of test } \\
\text { waters considered } \\
\text { for bioavailability } \\
\text { modelling) }\end{array}$ \\
\hline $\begin{array}{l}\text { Cremazy } \\
\text { et al. } \\
2017\end{array}$ & $\begin{array}{l}\text { Rainbow } \\
\text { trout }\end{array}$ & $\begin{array}{l}\text { Juvenile } \\
\text { (5-10g) }\end{array}$ & 30d & survival & $\begin{array}{l}\mathrm{pH}: \text { 5.1-8.6; } \\
\text { Ca: } 2.4-77 \mathrm{mg} / \mathrm{L} ; \\
\text { Mg: } 1.0-75 \mathrm{mg} / \mathrm{L} \text {; } \\
\text { Na: } 2.5 \text { - } 8.5 \mathrm{mg} / \mathrm{L} \text {; } \\
\text { DOC: } 0.4-11 \\
\text { mg/L } \\
(n=13)\end{array}$ \\
\hline $\begin{array}{l}\text { Waiwood } \\
\& \\
\text { Beamish }\end{array}$ & $\begin{array}{l}\text { Rainbow } \\
\text { trout }\end{array}$ & $\begin{array}{l}\text { Juvenile } \\
\text { (6-10g) }\end{array}$ & 30d & survival & $\begin{array}{l}\text { pH: 6.0-8.0; } \\
\text { Ca: } 6.4-124\end{array}$ \\
\hline
\end{tabular}

This article is protected by copyright. All rights reserved. 


\begin{tabular}{|c|c|c|c|c|c|}
\hline 1978 a,b & & & & & $\begin{array}{l}\mathrm{mg} / \mathrm{L} ; \\
\mathrm{Mg}: 3.6-44 \mathrm{mg} / \mathrm{L} ; \\
\mathrm{Na}: 14 \mathrm{mg} / \mathrm{L} ; \\
\text { DOC: } 0.6-1.6 \\
\mathrm{mg} / \mathrm{L} \\
(\mathrm{n}=6)\end{array}$ \\
\hline $\begin{array}{l}\text { OSU } \\
2016 b\end{array}$ & $\begin{array}{l}\text { Rainbow } \\
\text { trout }\end{array}$ & $\begin{array}{l}\text { Early life stage } \\
\text { (Fertilised } \\
\text { embryo (19 dpf) } \\
\text { to swim-up } \\
\text { larvae) }\end{array}$ & $52 d^{\mathrm{a}}$ & $\begin{array}{l}\text { survival, larval } \\
\text { weight }\end{array}$ & $\begin{array}{l}\text { pH: 6.1-7.0; } \\
\text { Ca: } 9.6 \mathrm{mg} / \mathrm{L} ; \\
\text { Mg: } 4.6 \mathrm{mg} / \mathrm{L} ; \\
\text { Na } 15 \text { mg/L; } \\
\text { DOC: } 1.1-1.4 \\
\text { mg/L } \\
(n=2)\end{array}$ \\
\hline $\begin{array}{l}\text { Erickson } \\
\text { et al. } \\
1996\end{array}$ & $\begin{array}{l}\text { Fathead } \\
\text { minnow }\end{array}$ & $\begin{array}{l}\text { Early life stage } \\
\text { (larvae }<24 \mathrm{~h} \\
\text { old) }\end{array}$ & $7 d$ & $\begin{array}{l}\text { survival, dry } \\
\text { weight, growth } \\
\text { rate }\end{array}$ & $\begin{array}{l}\text { pH: } 6.6 \text {-8.7; } \\
\text { Ca: } 14 \text { mg/L; } \\
\text { Mg: } 3 \text { - } 52 \text { mg/L; }\end{array}$ \\
\hline
\end{tabular}

This article is protected by copyright. All rights reserved. 


\begin{tabular}{|l|l|l|l|l|}
\hline & & & & Na: $2-48 \mathrm{mg} / \mathrm{L} ;$ \\
& & & & DOC NR \\
(n=8)
\end{tabular}

${ }^{\text {a }} 10 \mathrm{~d}$ embryo $+12 \mathrm{~d}$ alevin $+30 \mathrm{~d}$ swim-up

$\mathrm{dpf}=$ days post fertilization, $\mathrm{DOC}=$ dissolved organic carbon, $\mathrm{DOC} \mathrm{NR}=\mathrm{DOC}$ not reported; $\mathrm{n}=$ number of waters investigated.

This article is protected by copyright. All rights reserved. 
Table 2. Overview of parameters of the chronic Cu gBAM for juvenile rainbow trout (RT; Oncorhynchus mykiss) and comparison with different pre-existing chronic $\mathrm{Cu}$ fish BLMs

\begin{tabular}{|l|l|l|l|}
\hline & Juvenile & Chronic & Cu VRAR \\
& rainbow & juvenile RT & Fish BLM (De \\
trout & BLM of & Schamphelaere \\
gBAM & Cremazy et & \& Janssen \\
(Present & al. (2017) & 2008) \\
\hline SpH & study) & & \\
\hline Log KCaBL & 4.0 & 4.0 & 3.5 \\
\hline Log KMgBL & 3.4 & 3.4 & 3.6 \\
\hline Log KNaBL & 3.0 & 3.0 & 3.2 \\
\hline Log KCuBL & -0.449 & - & \\
\hline & - & 5.8 & 5.4 \\
\hline
\end{tabular}

This article is protected by copyright. All rights reserved. 


\begin{tabular}{|l|l|l|l|}
\hline Log & - & 6.5 & 7.32 \\
KCuOHBL & & & \\
\hline $\begin{array}{l}\text { Log } \\
\text { KCuCO3BL }\end{array}$ & & - & 7.01 \\
\hline
\end{tabular}

gBAM= generalized bioavailability model; $\mathrm{BLM}=$ biotic ligand model, VRAR= voluntary risk assessment report

This article is protected by copyright. All rights reserved. 